www.jmscr.igmpublication.org

Impact Factor (SJIF): 6.379

Index Copernicus Value: 79.54

ISSN (e)-2347-176x ISSN (p) 2455-0450

crossrefDOI: https://dx.doi.org/10.18535/jmscr/v6i12.66

\title{
Knowledge about HIV and attitude towards HIV infected individuals among nursing professionals working in Sagar town, Madhya Pradesh, India
}

\author{
Authors \\ Dr Prayank Jain MD, DM, Dr Achla Jain MBBS \\ Corresponding Author \\ Dr Achla Jain MBBS \\ PG trainee in Community Medicine
}

\section{Background}

Globally, 36.9 million people are living with HIV (according to latest data available in 2017) of which 1.5 million are children below 15 years of age $^{[1]}$. About 9.4 million people did not even know that they were living with $\mathrm{HIV}^{[1]}$. Out of 36.9 million, only 21.7 million (59\%) people living with HIV were accessing antiretroviral therapy ${ }^{[1]} .65 \%$ of female adults aged 15 years and older had access to treatment and $53 \%$ of male adults aged 15 years and older had access to $\mathrm{ART}^{[1]}$. In 2017, 80\% of pregnant women living with HIV had access to antiretroviral medicines to prevent transmission of HIV to their babies ${ }^{[1]}$. Globally since 2010, new HIV infections have declined by an estimated $16 \%$, from 1.9 million to 1.6 million in $2017^{[1]}$. Since 2010, new HIV infections among children have declined by $35 \%$, from 270000 in 2010 to 180000 in $2017^{[1]}$.In India 2.1 million people are living with HIV and only $56 \%$ are accessing $\mathrm{ART}^{[1]}$. India has shown remarkable progress in reducing new cases of HIV and incidence of new cases have reduced by $27 \%$ since $2010^{[1]}$. Given the large burden of disease in a resource limited country like India, in depth knowledge and caring attitude towards HIV infected individuals among nursing professionals is of great importance to reduce morbidity of those infected and to help reduce transmission of disease in community.

\section{Objective}

1) Knowledge about HIV and attitude towards HIV infected individuals among nursing professionals working in Sagar town, Madhya Pradesh, India.

\section{Methods}

A cross-sectional study was conducted among 30 nursing professionals, using a predesigned, self administered questionnaire on awareness about transmission, prevention and treatment of HIV infection. Questions to assess attitude of nursing professionals towards care and management of HIV infected individuals were also included.

\section{Results}

All nursing professionals heard about HIV and knew that the causative agent is a virus. All of them knew that diagnostic tests are available. 26 out of 30 believed that disease is incurable.19 out of 30 believed that no treatment is available for 
HIV.13 out of 30 believed that vaccine is available for prevention of HIV. Only 15 out of 30 knew correctly about the modes of transmission. 3 out of 30 believed that doctors and nurses should be allowed to refuse to care for people with HIV/AIDS.4 out of 30 said that they are not willing to assist an operation on people with HIV/AIDS.10 out of 30 said that they would prefer not to take responsibility of caring for people with HIV/AIDS. All 30 subjects believed that all surgical patients should be routinely screened for HIV. 29 out of 30 believed that all obstetric patients should be routinely screened for HIV.15 out of 30 said that they are not willing to perform mouth to mouth resuscitation on patients with HIV/AIDS. All subjects believed that their professional education has provided them with enough information to work with HIV patients.

\begin{tabular}{|c|c|c|}
\hline QUESTION & \multicolumn{2}{|c|}{ RESPONSE } \\
\hline $\begin{array}{ll}\text { HEARD } & \text { ABOUT } \\
\text { HIV/AIDS } & \end{array}$ & $\mathrm{YES}=30$ & $\mathrm{NO}=0$ \\
\hline CAUSATIVE AGENT & VIRUS $=30$ & OTHER $=0$ \\
\hline $\begin{array}{ll}\text { DIAGNOSTIC } & \text { TESTS } \\
\text { AVAILABLE } & \\
\end{array}$ & YES $=30$ & $\mathrm{NO}=0$ \\
\hline $\begin{array}{l}\text { TREATMENT } \\
\text { AVAILABLE }\end{array}$ & $\mathrm{YES}=11$ & $\mathrm{NO}=19$ \\
\hline DISEASE IS CURABLE & $\mathrm{YES}=4$ & $\mathrm{NO}=26$ \\
\hline VACCINE AVAILABLE & $\mathrm{YES}=13$ & $\mathrm{NO}=17$ \\
\hline $\begin{array}{ll}\text { MODES } & \text { OF } \\
\text { TRANSMISSION } & \end{array}$ & $\begin{array}{c}\text { KNEW } \\
\text { CORRECT } \\
\text { LY=15 }\end{array}$ & $\begin{array}{c}\text { DID NOT } \\
\text { KNEW } \\
\text { CORRECTLY } \\
=15\end{array}$ \\
\hline $\begin{array}{l}\text { NURSES SHOULD BE } \\
\text { ALLOWED TO REFUSE } \\
\text { CARING FOR PATIENT } \\
\text { OF HIV/AIDS }\end{array}$ & YES=3 & $\mathrm{NO}=27$ \\
\hline $\begin{array}{lr}\text { WILLING TO } & \text { ASSIST } \\
\text { OPERATION } & \text { ON } \\
\text { PATIENTS } & \text { WITH } \\
\text { HIV/AIDS } & \\
\end{array}$ & $\mathrm{YES}=26$ & $\mathrm{NO}=4$ \\
\hline $\begin{array}{lcr}\text { PREFER } & \text { TO } & \text { TAKE } \\
\text { CARE OF } & \text { PERSON } \\
\text { WITH HIV/AIDS } & \end{array}$ & $\mathrm{YES}=20$ & $\mathrm{NO}=10$ \\
\hline $\begin{array}{l}\text { ALL } \\
\text { PATIENTS SHOULD BL } \\
\text { SCREENED FOR HIV }\end{array}$ & $\mathrm{YES}=30$ & $\mathrm{NO}=0$ \\
\hline $\begin{array}{lr}\text { ALL } & \text { OBSTETRIC } \\
\text { PATIENTS SHOULD BE } \\
\text { SCREENED FOR HIV }\end{array}$ & $\mathrm{YES}=29$ & $\mathrm{NO}=1$ \\
\hline \begin{tabular}{lr}
\multicolumn{2}{l}{ WILLING TO PERFORM } \\
MOUTH TO MOUTH \\
RESUSCITATION \\
PATIENTS
\end{tabular} & YES $=15$ & $\mathrm{NO}=15$ \\
\hline
\end{tabular}

\begin{tabular}{|l|l|l|}
\hline HIV/AIDS & & \\
\hline BELIEVED THAT THEIR & YES=30 & NO=0 \\
PROFESSIONAL & & \\
EDUCATION HAS & & \\
PROVIDED THEM WITH & & \\
ENOUGH & \\
INFORMATION TO & & \\
WORK WITH HIV & & \\
PATIENTS. & & \\
\hline
\end{tabular}

\section{Conclusion}

The overall awareness regarding transmission and treatment of HIV/AIDS was found to be extremely low in nursing professionals under study. The overall attitude of care for HIV/AIDS patients was disappointing as many nursing professionals were averse to care for such patients. The results of this study show the poor level of education regarding HIV/AIDS in nursing colleges in this region. Initiatives to improve level of education among nursing students and continuous medical education among nursing professionals is required to ensure better care of patients with HIV/AIDS and also to reduce burden of disease in community.

\section{References}

1. http://aidsinfo.unaids.org/ 